\title{
MESONEPHRIC ADENOCARCINOMA OF ENDOCERVIX WITH LOBULAR MESONEPHRIC HYPERPLASIA: CASE REPORT
}

\author{
Mario Puljiz ${ }^{1}$, Damir Danolić ${ }^{1}$, Lucija Kostić ${ }^{1}$, Ilija Alvir ${ }^{1}$, Darko Tomica ${ }^{1}$, Ivica Mamić ${ }^{1}$, \\ Ivana Vlastelica Munivrana ${ }^{2}$, Marko Puljiz ${ }^{3}$, Danko Velimir Vrdoljak ${ }^{4}$ and Melita Perić Balja ${ }^{5}$ \\ ${ }^{1}$ Department of Gynecologic Oncology, University Hospital for Tumors, Sestre milosrdnice University \\ Hospital Center, Zagreb; ${ }^{2}$ Department of Anesthesiology and Intensive Care, Šibenik General Hospital, Šibenik; \\ ${ }^{3}$ School of Medicine, University of Split, Split; ${ }^{4}$ Department of Surgical Oncology, ${ }^{5}$ Department of Clinical \\ Pathology, University Hospital for Tumors, Sestre milosrdnice University Hospital Center, Zagreb, Croatia
}

\begin{abstract}
SUMMARY - Mesonephric adenocarcinoma is a rare variant of cervical adenocarcinoma. We present a case of mesonephric adenocarcinoma of endocervix with cervical and vaginal lobular mesonephric hyperplasia in a 57-year-old woman. Vaginal bleeding persisting for 12 months was the only symptom. Histopathologic findings and characteristic immunophenotype are crucial for the diagnosis. The tumor was composed of papillary formation with a central fibrovascular stroma, villoglandular and densely compact tubular structures containing intraluminal eosinophilic secretion, and coated with one or more rows of cylindrical atypical epithelial cells. There were 30 pathologic mitotic shapes found per $10 \mathrm{HPF}$. The tumor invaded nearly full-thickness of cervical stroma with positive lymphovascular space invasion and clear margins. The case demonstrated characteristic cytokeratin 7, vimentin and epithelial membrane antigen positivity and high Ki-67 proliferation index (60\%). Estrogen receptors, progesterone receptors and carcinoembryonic antigen were negative. Intratubular lumen secretion was periodic acid-Schiff positive with periodic acid-Schiff negative carcinoma cells. Differential diagnoses include adenoma malignum, well-differentiated villoglandular adenocarcinoma, endometrioid adenocarcinoma, serous adenocarcinoma, mesonephric adenocarcinoma with a sarcomatous component, clear-cell carcinoma and mesonephric hyperplasia. Radical hysterectomy with bilateral salpingo-oophorectomy, pelvic and para-aortic lymphadenectomy was performed. Three years after the surgery, the patient remains well. There has not been any evidence of local or distant recurrence. There are no specific recommendations for the treatment of this rare disease. It remains uncertain whether surgical approach is sufficient or the treatment should include additional radio/chemotherapy.
\end{abstract}

Key words: Uterine cervical neoplasms - diagnosis; Uterine cervical neoplasms - pathology; Uterine cervical neoplasms - surgery; Adenocarcinoma - diagnosis; Adenocarcinoma - surgery; Mesonephroma diagnosis; Mesonephroma - pathology; Hyperplasia; Cytodiagnosis; Vagina - pathology; Case reports

\section{Introduction}

Malignant mesonephric tumors are derived from remnants of the mesonephric (wollfian) ducts. In the

Correspondence to: Damir Danolic, MD, Department of Gynecologic Oncology, University Hospital for Tumors, Sestre milosrdnice University Hospital Center, Ilica 197, HR-10000 Zagreb, Croatia E-mail: damir.danolic@gmail.com

Received November 19, 2014, accepted February 16, 2016 absence of testosterone, the mesonephric ducts regress. Remnants may persist as the epoophoron, Skene's glands and Gartner's duct. They are usually located in the uterine cervix, lateral wall of the vagina, broad ligament, mesosalpinx and in the ovarian hilium ${ }^{1}$. Mesonephric duct remnants are found in $10 \%-22 \%$ of adult uterine cervices ${ }^{2,3}$. Hyperplasia of these remnants is a benign lesion that is almost always discovered incidentally in cone biopsy or hysterectomy specimens ${ }^{1,4}$. Ma- 
lignant mesonephric tumor, arising from mesonephric duct hyperplasia or mesonephric remnants, is an extremely rare variant of cervical adenocarcinoma ${ }^{5}$, with 35 cases reported in the literature ${ }^{4,6,7}$. We present a case of mesonephric adenocarcinoma of uterine cervix associated with lobular mesonephric hyperplasia. Clinical, pathological and immunohistochemical characteristics are discussed.

\section{Case Report}

A 57-year-old postmenopausal woman presented for vaginal bleeding persisting for 12 months. Endocervical curettage and cervical adenocarcinoma diagnosis were made at an external institution. Her previous medical history was not significant and included only hypertension. Physical examination revealed appropriate external genitals, medium large vagina with some active bleeding from the uterine cervix. There were no signs of infection, inflammation or other abnormalities of uterine cervix. Uterus was of normal size, movable and painless. Bilateral parametria were free. Transvaginal ultrasonography showed a 5.6x4.5 $\mathrm{cm}$ solid mass in the uterine corpus and $1.9 \times 2.7 \mathrm{~cm}$ hyperechoic formation in the uterine cervix. Magnetic resonance imaging (MRI) showed a uterine cervical mass measuring $4 \mathrm{~cm}$ in diameter. There was no significant lymphadenopathy. The patient underwent radical hysterectomy with bilateral salpingo-oophorectomy, pelvic and para-aortic lymphadenectomy. Postoperative period passed without any complications. Histopathologic and immunohistochemical analysis confirmed the diagnosis of mesonephric adenocarcinoma of uterine cervix, lobular mesonephric hyperplasia, adenomyosis and leiomyoma of the uterus. The macroscopic intersection of the hysterectomy specimen showed a soft tumor mass measuring $5.5 \times 4$ $\mathrm{cm}$ in the cervix and lower uterine segment. The tumor was composed of papillary formation with central fibrovascular stroma (Fig. 1), villoglandular and densely compact tubular structures containing intraluminal eosinophilic secretion, and coated with one or more rows of cylindrical atypical epithelial cells with vesicular nuclei which were interspersed and had the appearance of ground glass. There were 30 pathologic mitotic shapes found per 10 high power fields (HPF). The tumor invaded nearly full-thickness of cervical stroma with positive lymphovascular space invasion and clear

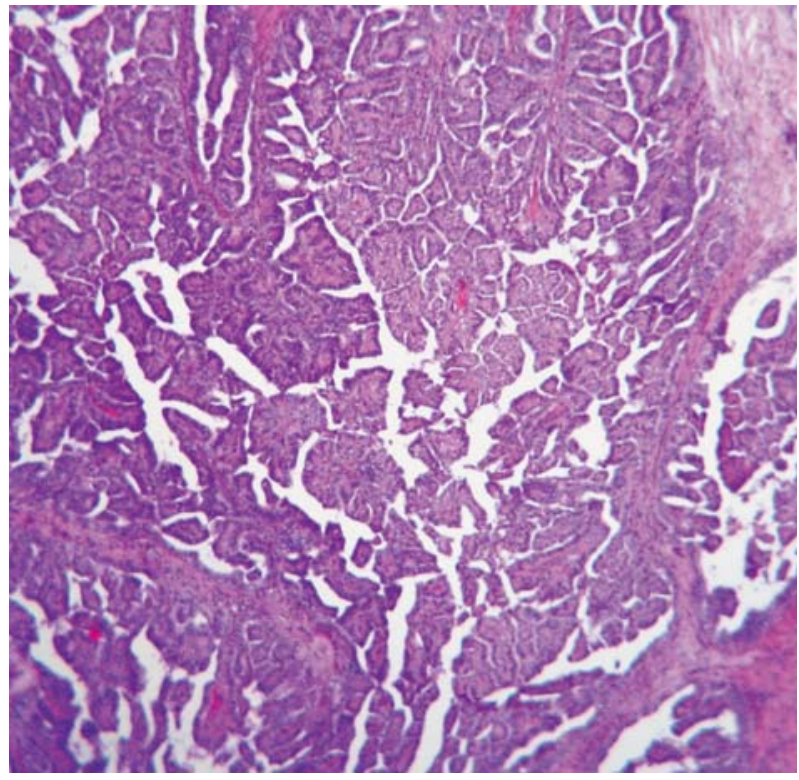

Fig. 1. Mesonephric adenocarcinoma composed of papillary formation with central fibrovascular stroma.

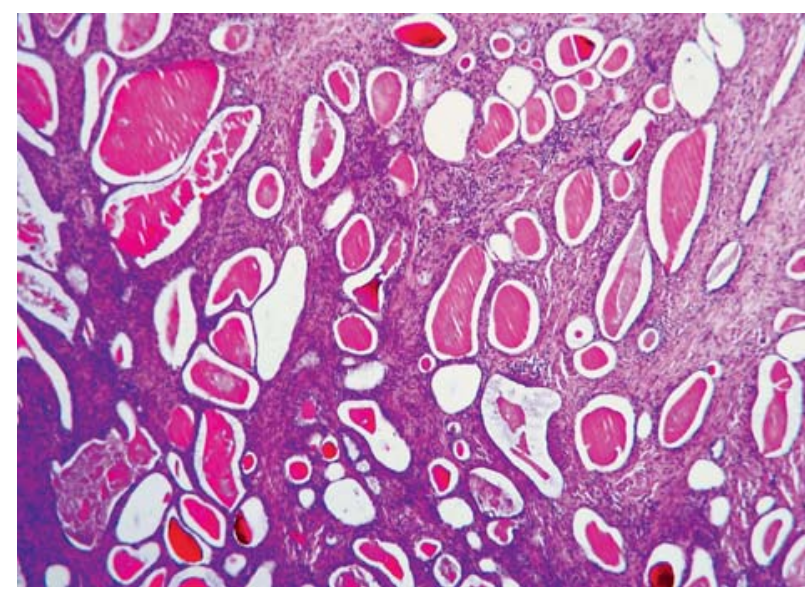

Fig. 2. Lobular mesonephric hyperplasia.

margins. In the adjacent area of adenocarcinoma, lobular mesonephric hyperplasia was observed (Fig. 2). The hyperplastic mesonephric tubules were also found in fornices of the vagina, also containing intraluminal eosinophilic secretion. Compared to adenocarcinoma, there was no cytologic atypia.

Immunohistochemically, neoplastic cells were diffusely positive for cytokeratin 7 , vimentin, epithelial membrane antigen (EMA), and focally positive for p53. The adenocarcinoma component was negative for estrogen receptors (ER), progesterone receptors (PR), and carcinoembryonic antigen (CEA). Proliferation 
index $\mathrm{Ki}-67$ was $60 \%$. The intratubular lumen secretion was periodic acid-Schiff (PAS) positive, while that stain was absent in the adenocarcinoma cells. Based on these morphological and immunohistochemical features, the diagnosis of mesonephric adenocarcinoma, International Federation of Gynecology and Obstetrics (FIGO) IB2, with lobular mesonephric hyperplasia was confirmed. Para-aortic $(n=12)$ and pelvic $(n=32)$ lymph nodes were negative for metastasis. The patient has had regular checkups. To date, three years after the surgery, the patient remains well. There has not been any evidence of local or distant recurrence.

\section{Discussion}

Proliferative mesonephric lesions are extremely rare. Our patient was aged 57, and according to Anagnostopoulos et al. ${ }^{7}$, the mean age of patients with mesonephric adenocarcinomas of uterine cervix was 50.7 years, age range between 24 and 73 years. Usually, most cases were diagnosed at an early stage of the disease, FIGO IB, presenting with abnormal vaginal bleeding, pelvic pain, dyspareunia, uterine prolapse or abnormal Pap smear ${ }^{6-8}$. In this particular case, the disease was diagnosed at an early stage, more precisely FIGO IB2. Abnormal vaginal bleeding was the only symptom. The etiology of mesonephric adenocarcinoma is not related to the human papillomavirus ${ }^{8}$.

The combination of histopathologic and immunohistochemical analysis of tumor tissue is crucial in differential diagnosis of most cervical glandular lesions. Mesonephric adenocarcinomas of uterine cervix, which are presumed to arise from mesonephric hyperplasia or mesonephric remnants, are characterized by morphological diversity and an unusual appearance ${ }^{6}$. Differential diagnoses include adenoma malignum, well-differentiated villoglandular adenocarcinoma, endometrioid adenocarcinoma, serous adenocarcinoma, mesonephric adenocarcinoma with a sarcomatous component, clear-cell carcinoma and mesonephric hyperplasia ${ }^{6,7,9}$. In almost all cases reported in the literature, mesonephric hyperplasia classified as diffuse mesonephric hyperplasia, ductal mesonephric hyperplasia and lobular mesonephric hyperplasia was observed adjacent to mesonephric adenocarcinoma, especially lobular and diffuse subtypes ${ }^{6}$. These categories of mesonephric hyperplasia have no clinical significance but they may be misinterpreted as premalignant or malignant lesions and pathologists should be aware of this possibility ${ }^{4,10}$. In our case, lobular mesonephric hyperplasia was found next to the area of adenocarcinoma and also in fornices of the vagina, but compared to adenocarcinoma, there was no cytologic atypia. The diffuse form of mesonephric hyperplasia may extend deeply into the cervical wall mimicking minimal deviation adenocarcinoma ${ }^{11}$.

Appropriate patient management requires correct classification of mesonephric lesions. The histopathologic characteristics of mesonephric adenocarcinoma that help differentiate these lesions from adenoma malignum are cytologic atypia and lack of intracytoplasmic mucin ${ }^{6}$. The presence of sarcomatous components is the key to carcinosarcoma diagnosis ${ }^{8}$. Only $16 \%$ of carcinosarcomas reported in the English literature were of mesonephric duct origin ${ }^{2}$. The typical histologic features of clear-cell cytoplasm and hobnail cell pattern, and the presence of PAS positive intraluminal secretion with PAS positive intracytoplasmic globules direct us to the diagnosis of clear-cell carcinoma ${ }^{9}$. The absence of mesonephric hyperplasia is associated with endometrioid adenocarcinoma and clear-cell carcino$\mathrm{ma}^{6}$. Our case demonstrated characteristic cytokeratin 7, vimentin and EMA positivity, high Ki-67 proliferation index (60\%), negative ER, PR, CEA and PAS positive intraluminal secretion with PAS negative carcinoma cells. Recent reports showed that immunohistochemical features of mesonephric adenocarcinoma included positivity for epithelial markers including pancytokeratin, CK7, CAM5.2 and EMA ${ }^{7,9}$. Vimentin is positive in $70 \%$ and calretinin in $88 \%$ of cervical mesonephric adenocarcinoma, while CK20, ER, PR and CEA are usually negative ${ }^{7,9}$. This staining profile is crucial in the differential diagnosis, especially with endometrioid and other paramesonephric adenocarcinomas, with which it may be confused. The expression of p53 and/or CD10 is also useful in establishing the diagnosis of mesonephric neoplasm. CD10 has been suggested as a marker for all mesonephric lesions in the female genital tract, although there are cases of CD10 negative mesonephric adenocarcinomas reported in the literature ${ }^{4,6,9}$. Most other benign endocervical glandular lesions are negative for $\mathrm{CD} 10^{4}$. A high Ki$67(>40 \%)$ proliferative index is a feature of malignant lesions $^{12}$. 
There are no definite recommendations for the treatment and follow up of this uncommon disease. According to the current guidelines for cervical adenocarcinoma, surgery should be the primary choice for localized disease $\mathrm{e}^{13,14}$. Surgical treatment implies radical hysterectomy, pelvic lymphadenectomy and, for patients with larger tumors and/or positive pelvic lymph nodes, para-aortic lymphadenectomy ${ }^{13,14}$. According to Bague et al. ${ }^{15}$, surgery alone should be the treatment of choice. In our case, surgery was the only treatment and three years thereafter, there has been no evidence of local or distant recurrence. The role of chemotherapy and radiotherapy is unclear; there is little evidence for their efficacy ${ }^{3}$. Postoperative radiotherapy decreases the risk of disease progression to stage IB cervical cancer, with doubtful impact on overall survival ${ }^{16}$. A review of the literature showed that chemotherapy might be considered as palliative treatment in patients with recurrence ${ }^{3,17,18}$. According to Anagnostopoulos et al. ${ }^{7}$, the mean disease-free interval for stage IB disease is 48.6 months, with recurrence rate of $23 \%$ after surgery as primary treatment.

\section{Conclusion}

This case report draws attention to the importance of considering mesonephric adenocarcinoma in the differential diagnosis of cervical carcinoma. Although this type of tumor is rare, it is necessary to define specific recommendations for treatment, which would lead to better follow up and overall survival. Our case contributes to the scarce knowledge of this rare disease and can help in proposing the treatment and follow up guidelines.

\section{References}

1. Huffman JW. Mesonephric remnants in the cervix. Am J Obstet Gynecol. 1948;56:23-40.

2. Meguro S, Yasuda M, Shimizu M, Kurosaki A, Fujiwara K. Mesonephric adenocarcinoma with a sarcomatous component, a notable subtype of cervical carcinosarcoma: a case report and review of the literature. Diagn Pathol. 2013;8:74, http://dx.doi. org/10.1186/1746-1596-8-74.

3. Montagut C, Mármol M, Rey V, Ordi J, Pahissa J, Rovirosa A, et al. Activity of chemotherapy with carboplatin plus paclitaxel in a recurrent mesonephric adenocarcinoma of the uterine corpus. Gynecol Oncol. 2003;90:458-61.

4. Menon S, Kathuria K, Deodhar K, Kerkar R. Mesonephric adenocarcinoma (endometrioid type) of endocervix with diffuse mesonephric hyperplasia involving cervical wall and myometrium: an unusual case report. Indian J Pathol Microbiol. 2013;56:51-3, http://dx.doi.org/10.4103/0377-4929.116150.

5. Yap OW, Hendrickson MR, Teng NN, Kapp DS. Mesonephric adenocarcinoma of the cervix: a case report and review of the literature. Gynecol Oncol. 2006;103:1155-8.

6. Fukunaga M, Takahashi H, Yasuda M. Mesonephric adenocarcinoma of the uterine cervix: a case report with immunohistochemical and ultrastructural studies. Pathol Res Pract. 2008; 204:671-6, http://dx.doi.org/10.1016/j.prp.2008.01.008.

7. Anagnostopoulos A, Ruthven S, Kingston R. Mesonephric adenocarcinoma of the uterine cervix and literature review. BMJ Case Rep. 2012;2012. pii: bcr0120125632, http://dx.doi.org/ 10.1136/bcr.01.2012.5632.

8. Tseng CE, Chen $\mathrm{CH}$, Chen SJ, Chi CL. Tumor rupture as an initial manifestation of malignant mesonephric mixed tumor: a case report and review of the literature. Int J Clin Exp Pathol. 2014;7:1212-7.

9. Erşahin C, Huang M, Potkul RK, Hammadeh R, Salhadar A. Mesonephric adenocarcinoma of the vagina with a 3-year follow-up. Gynecol Oncol. 2005;99:757-60.

10. Nucci MR. Pseudoneoplastic glandular lesions of the uterine cervix: a selective review. Int J Gynecol Pathol. 2014;33:330-8, http://dx.doi.org/10.1097/PGP.0000000000000139.

11. Seidman JD, Tavassoli FA. Mesonephric hyperplasia of the uterine cervix: a clinicopathologic study of 51 cases. Int J Gynecol Pathol. 1995;14:293-9.

12. Cina SJ, Richardson MS, Austin RM, Kurman RJ. Immunohistochemical staining for Ki-67 antigen, carcinoembryonic antigen, and p53 in the differential diagnosis of glandular lesions of the cervix. Mod Pathol. 1997;10:176-80.

13. Landoni F, Maneo A, Colombo A, Placa F, Milani R, Perego P, et al. Randomised study of radical surgery versus radiotherapy for stage Ib-IIa cervical cancer. Lancet. 1997;350:535-40.

14. Landoni F, Maneo A, Cormio G, Perego P, Milani R, Caruso $\mathrm{O}$, et al. Class II versus class III radical hysterectomy in stage IB-IIA cervical cancer: a prospective randomized study. Gynecol Oncol. 2001;80:3-12.

15. Bagué S, Rodríguez IM, Prat J. Malignant mesonephric tumors of the female genital tract: a clinicopathologic study of 9 cases. Am J Surg Pathol. 2004;28:601-7.

16. Rogers L, Siu SS, Luesley D, Bryant A, Dickinson HO. Radiotherapy and chemoradiation after surgery for early cervical cancer. Cochrane Database Syst Rev. 2012;5:CD007583, http://dx.doi.org/10.1002/14651858.CD007583.pub3.

17. Clement PB, Young RH, Keh P, Ostör AG, Scully RE. Malignant mesonephric neoplasms of the uterine cervix. A report of eight cases, including four with a malignant spindle cell component. Am J Surg Pathol. 1995;19:1158-71.

18. Silver SA, Devouassoux-Shisheboran M, Mezzetti TP, Tavassoli FA. Mesonephric adenocarcinomas of the uterine cervix: a study of 11 cases with immunohistochemical findings. Am J Surg Pathol. 2001;25:379-87. 


\title{
Sažetak MEZONEFRIČKI ADENOKARCINOM ENDOCERVIKSA
S LOBULARNOM MEZONEFRIČKOM HIPERPLAZIJOM: PRIKAZ SLUČAJA
}

\author{
M. Puljiz, D. Danolić, L. Kostić, I. Alvir, D. Tomica, I. Mamic, I. Vlastelica Munivrana, M. Puljiz, \\ D. V. Vrdoljaki M. Perić Balja
}

Mezonefrički adenokarcinom je rijedak oblik adenokarcinoma vrata maternice. Prikazujemo slučaj pedesetsedmogodišnje bolesnice s mezonefričkim adenokarcinomom vrata maternice, cervikalnom i vaginalnom lobularnom mezonefričkom hiperplazijom. Jedini simptom bilo je vaginalno krvarenje u trajanju od 12 mjeseci. Patohistološki nalaz i imunohistokemijska analiza ključni su u postavljanju konačne dijagnoze. Tumor je bio građen od papilarnih formacija s centralnom fibrovaskularnom stromom, viloglandularnih i gusto kompaktnih tubularnih struktura s eozinofilnom intraluminalnom sekrecijom koje su obložene jednim ili više redova cilindričnih atipičnih epitelnih stanica. Naš slučaj je pokazao karakteristično pozitivan citokeratin 7, vimentin i epitelni membranski antigen, visok Ki-67 indeks proliferacije (60\%). Estrogenski receptori, progesteronski receptori i karcinoembrijski antigen bili su negativni. Intratubularna sekrecija bila je PAS (engl. periodic acid-Schiff) pozitivna, a stanice karcinoma bile su PAS negativne. Diferencijalna dijagnoza uključuje maligni adenom, dobro diferencirani viloglandularni adenokarcinom, endometrioidni adenokarcinom, serozni adenokarcinom, mezonefrički adenokarcinom s komponentom sarkoma, karcinom svijetlih stanica i mezonefričku hiperplaziju. U bolesnice je učinjena radikalna histerektomija s obostranom adneksektomijom, zdjelična i paraaortna limfadenektomija. Tri godine nakon operacije u bolesnice nema znakova lokalnog recidiva niti udaljenih metastaza. Zbog malog broja opisanih slučajeva ne postoje preporuke za liječenje ovoga rijetkog patohistološkog oblika bolesti.

Ključne riječi: Uterini cervikalni tumori - dijagnostika; Uterini cervikalni tumori - patologija; Uterini cervikalni tumorikirurgija; Adenokarcinom - dijagnostika; Adenokarcinom - krirugija; Mezonefrom - dijagnostika; Mezonefrom - patologija; Hiperplazija; Citodijagnostika; Vagina - patologija; Prikazi slučaja 